\title{
University - State College Curriculum Model for Student Success in Engi- neering and Computer Science Programs
}

\section{Dr. Ali Zilouchian, Florida Atlantic University}

Dr. Ali Zilouchian is currently the Associate Dean for Academic Affairs and a professor in the College of Engineering and Computer Science at Florida Atlantic University. He is also currently the Director of "CAPTURE" program which is related to increasing pipeline, graduation rate as well as future jobs in the State of Florida related to STEM graduates especially Computer Science and Engineering fields. His recent projects have been funded by DOE, Florida BOG, National Science Foundation, Florida Power and Lights (FPL), Broward County School district and several other sources. His recent research works related to alternative energy applications includes Maximum Power Point Tracking (MPPT) for Solar Systems, Proton Exchange Membrane Fuel Cell (PEMFC) and battery technology to transportation technology. In addition, he has conducted research on the applications of soft computing methodologies to industrial processes including, desalination processes, oil refineries, fuzzy control of jet engines, and fuzzy controllers for car engines. Dr. Zilouchian has published one book, and over 143 book chapters, scholarly journal papers, and refereed conference proceedings. He has supervised $20 \mathrm{Ph}$.D. and MS students to completion during his tenure at FAU. He has taught more than thirty (30) different courses related to engineering technology during his tenure at FAU. In 1996 and 2001, Dr. Zilouchian was awarded for the Excellence in Undergraduate Teaching at FAU. He has also received many awards including 1998 outstanding leadership award (IEEE, membership development), best organizer award(World Automation Congress, 2002), best paper award( WAC, 2002), 2003 and 2004 College of Engineering Dean's awards in recognition of his contributions toward achievement of the goals of College of Engineering and Computer Science at FAU. He has served as session chair and organizer of many sessions in the international conferences for the past 30 years. Professor Zilouchian is currently an associate editor of the International Journal of Electrical and Computer Engineering out of Oxford, UK. Professor Zilouchian is senior member of several professional societies including Tau Beta Pi, Sigma Xi, Phi Kappa Phi, ASEE and IEEE.

\section{Dr. Nancy Romance, Florida Atlantic University}

Dr. Romance is Professor of Science Education in the College of Education at Florida Atlantic University (FAU) and a graduate faculty member in both the College of Engineering and Computer Science and the College of Science at FAU.Her research interests address meaningful learning in complex STEM domains, applying a learning sciences lens in addressing issues ranging from building elementary teachers knowledge and skill in teaching science to coordinating learning communities addressing mathematics curriculum as a persistent barrier impacting student success and retention in undergraduate STEM programs. She is currently OI on a NSF DR K-12, Co-PI on a USDOE Title III Hispanic Serving Institution, internal evaluator on FAU's NSF Advance early phase grant, and a member of the Advisory Board on the NSF STEM+C in Broward Schools and the NSF MSP at the University of Toledo.

\section{Ms. Dana Hamadeh, Palm Beach State College}

Dana Hamadeh earned a Bachelor of Science in Computer Engineering and a Master of Education in Curriculum and Instruction with a minor in Mathematics. Some of her professional experiences include over ten years teaching college mathematics, supervising student learning center for physics and mathematics, managing million dollar STEM grant programs, and serving as Associate Dean of STEM Academic Affairs at Palm Beach State College. She continues to develop and present dynamic and interactive staff, faculty, and student workshops and seminars on various academic and professional related topics. She feels privileged and blessed to wake up every morning doing what she loves to do.

\section{Ms. Annie Laurie Myers, Broward College}

Annie Myers - A dynamic, forthright leader who engages her faculty and students in partnerships for success in process and performance, she exudes positive energy and has the ability to energize others. A hybrid leader, with 22 years of supervisory, management, and leadership experience from the newspaper 
industry, proficient in both operations and information systems. Annie has been teaching in Computer Science and IT for over 16 years.

Associate Dean at Broward College and teaching since 2002, providing leadership and policy advice on matters related to all teaching and academic support services which include courses within Baccalaureate degrees, Associate in arts, Associate in science, and Associate in Applied Science.

\section{Michael Vitale, East Carolina University}

DR. Vitale holds the Ph.D. in Educational Research and Instructional Psychology. 


\title{
University-State College Curriculum Model for Student Success in Engineering and Computer Science
}

\begin{abstract}
The paper presents the framework for successful collaboration among two state colleges (Palm Beach State College; Broward College) and a recent Hispanic Serving Institution (HSI) Title III university (Florida Atlantic University) with a combined 140,000+ undergraduate students. The initiative builds upon the Computer Accelerated Pipeline to Unlock Regional Excellence (CAPTURE) program sponsored by the Florida Board of Governor (BOG) and addresses curriculum mapping and articulation to support student degree completion in computer science and engineering programs. Specifically highlighted as part of the transfer model are curriculum alignment and mapping, degree-specific "flight" plans, and program-geared advising. The collected data validates the effectiveness of the proposed model in increasing both the student pipeline, and graduation rates. The process has also deepened our understanding of the needs of students to better align student careers aspirations with industry workforce needs. The effectiveness of the collaborative model could be replicated among other institutions interested in promoting engineering degrees among Hispanic and low income students also.
\end{abstract}

\section{$\underline{\text { Introduction }}$}

Achieving technological and scientific literacy is critical to ensuring America competitiveness in the $21^{\text {st }}$ century. We must engage students at all educational levels in order to maintain a broad pipeline of our future engineers and scientist. Recent data by U.S. Department of Education, National Center for Education Statistics (NCEA) shows that Florida is below the national average of advanced science and engineering degrees awarded as a share of science and engineering degrees conferred [1]. Engineer and computer occupations are expected to add more than a Million new jobs from 2016 to 2026, and, as a group, they will grow more than twice as fast as the average for all occupations in the economy, according to recent projections by the Department of Labor, Bureau of Labor Statistics [2]. The employment of software developers is projected to growth by $24 \%$ with system developer job growth projected $31 \%$ by the year 2026 [2]-[3]. Given the fact that the medical and health insurance carriers industry will also need innovative software packages to manage the health care, the exponential growth of more than $25 \%$ in the Information Technology (IT) sector is expected within the next decade also [4]. Furthermore, the US and World News Magazine has ranked the software development jobs as the number one job among the best one hundred jobs in 2016[4]. It is projected that by year $2020,35 \%$ of new job openings $(8.4 \mathrm{M})$ will require at least a bachelor degree, with STEM jobs as the fastest growing occupations according to a recent forecast on STEM occupations from the Georgetown University Center on Education and the Workforce [5].

According to the Florida Access and Educational Attainment Committee Report [6], the greatest demand for jobs, exceeding 2,000 projected positions is in STEM. The Annual Projected Under-Supply in Florida in Occupations Requiring a Bachelor's Degree in Computer Occupations is 2,361. Computer Occupations include: Computer Network Architects, Computer Systems Analysts, Computer Programmers, Software Developers and Graphic Designers. Based on regional workforce data from the Department of Economic Opportunity (DEO), 70\% of the computer occupations identified by the Commission's gap analysis are found in the four areas in State of Florida which represent six DEO workforce regions and sixteen counties. An 
area of high unfilled demand is the tri-county region served in South Florida by Florida Atlantic University (FAU), Broward College (BC) and Palm Beach State College (PBSC).

The proposed developed articulation agreement as presented herein has already produced more than 150 additional graduates with a Bachelor's Degree in computer science or computer engineering within the last three years. In this paper, the implementation of the program as well as the future direction of the HSI Title III project is reported.

\section{Project Overview}

Transitioning into college and successfully completing a STEM degree in computer science (CS), including computer engineering (CE) and electrical engineering (EE), have been identified as key factors associated with and the pathway to economic success and preparation for STEM careers. In Florida, and specifically south Florida, the economic indicators suggest that the field of CS offers a powerful potential career pathway with a large number of available jobs.

However, at the same time, economic data indicate that Hispanics and low-income workers are consistently among the most underrepresented groups in this career field. As a challenge, this project is designed to expand and diversify the STEM workforce in CS through a combination of gateway course improvements and student academic and motivation support. In doing so, the project will articulate a multi-institutional infrastructure that involves collaboration between 2year state colleges and a 4-year university that successfully transitions 2-year state college students pursuing CS degrees to the university for the completion of the BS degree in CS. In turn, students holding the BS degree in CS have a wide range of employment opportunities in a variety of settings (e.g., general business, industry, medicine, science, education, energy).

In working to develop student career potential, this project also recognizes a complex array of barriers faced by students in progressing through the academic pipeline toward earning a CS degree. In considering these barriers as challenges to be overcome, this project aligns with evidenced-based recommendations from the National Research Council (NRC)[7]-[10], the National Academy of Science (NAS), the National Academies of Sciences, Engineering and Medicine (NASEM)[11], National Academics of Engineering[12]-[14] as well as a large body of research from a variety of disciplines such as the learning sciences[15]-[20], instructional design, cognitive science, and educational leadership[21]-[24] .

The primary goal of our recent project is to facilitate the completion of undergraduate degrees in computer science, computer engineering, and electrical engineering (referred to hereafter as "computer science") by students who first begin their undergraduate academic programs and complete their Associate of Arts ( AA) degree at Palm Beach State College and Broward College (referred to hereafter as State Colleges) and then transfer, enroll and complete a BS degree Computer Science within the College of Engineering and Computer Science at Florida Atlantic University. Figure 1 overviews the major new DOE Title III project components. 


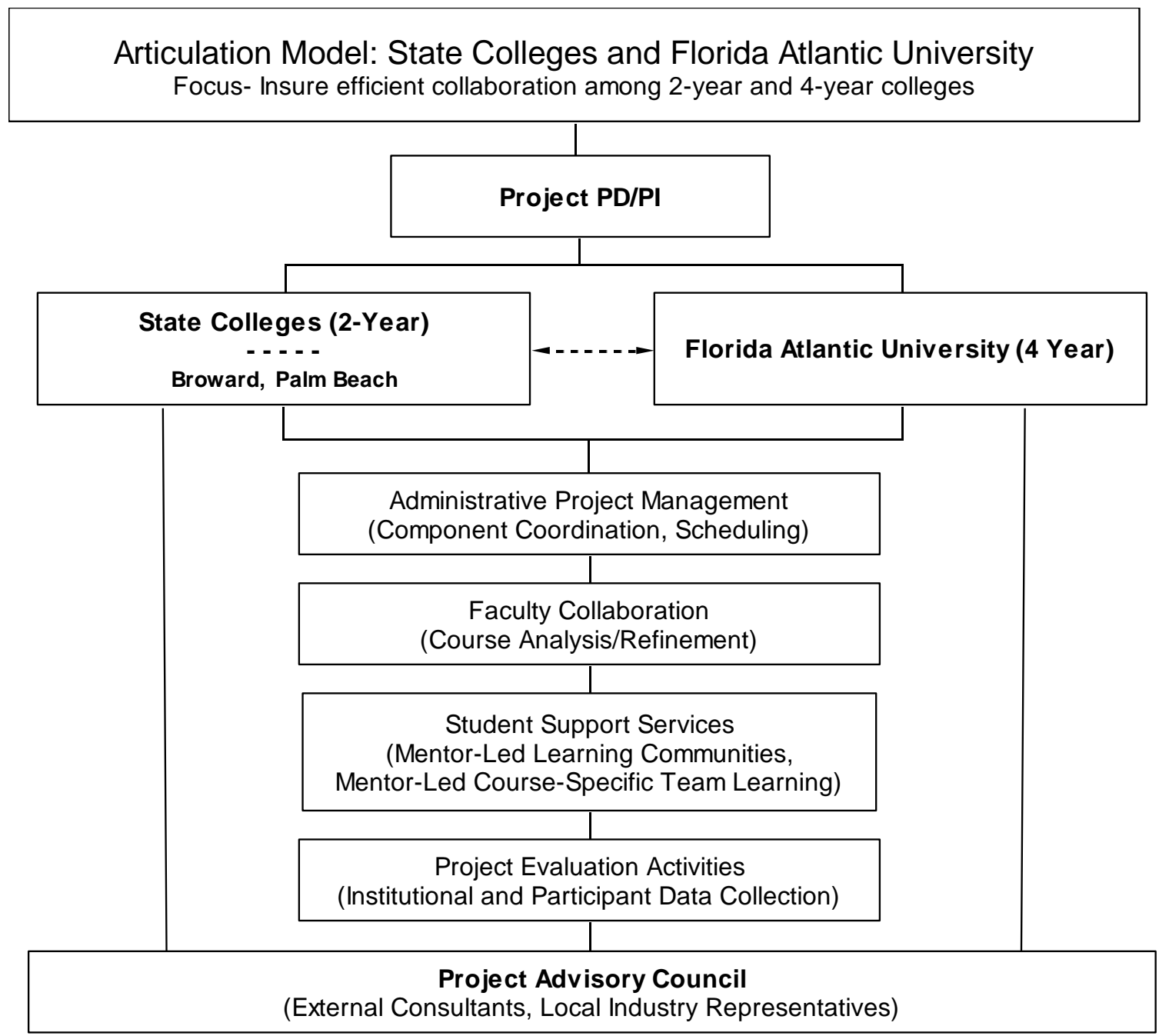

Figure 1. Overview of major project components.

In accomplishing project goals, the key components were designed to provide academic and motivational support for student participants throughout their enrollment at the State Colleges and FAU.

The above Articulation Model (Figure 1) provides the framework for the extensive collaboration between the 2-year State Colleges (PBSC, BC) and the upper division CS/CE and EE programs at FAU. Within the scope of the model, various intervention components have been implemented in order to attract and sustain students. The specific key components are as follow:

- Articulation agreement between State Colleges and FAU CS and CE. As executed by the three institutions (FAU, Broward College and Palm Beach State College), this agreement enabled the full implementation of a streamlined and seamless admission process from two State Collages to FAU. Students in HSI program at both state colleges can develop appropriate flight plans (i.e., courses of study) with the help of their academic advisors. Such flight plans assist students in monitoring their progress toward specific degree programs in CS, CE and EE 
each semester. The adaptation of individual flight plans is expected to be an important factor in increasing student retention and graduate rate as part of the student cohort transfer strategy from PBSC and BC to the College of Engineering and Computer Science at FAU. Please see Appendix A for a sample of the articulation agreement and the student flight plan.

- Curricular refinement of gateway courses in mathematics (College Algebra, Trigonometry, Pre-Calculus, and Calculus I) offered at the State colleges. Because these courses have high DFW (i.e., failure and withdrawal) rates, they serve as barriers to students whose intent is to major in computer science. The objective of the project curriculum refinement component in year 1 is to improve the conceptual structure for each of these mathematics courses so that they are optimally effective for State College students in terms of course achievement outcomes and retention in a STEM education degree track.

- Development of a course-specific mentoring support model to ensure student success in completing those gateway mathematics courses in which they are enrolled. The objective is to maximize the conceptual learning support provided to students enrolled in gateway mathematics courses to ensure successful course completion and provide the necessary prerequisite knowledge for success in subsequent math courses. In addition to the math learning support, the mentors will also provide complementary guidance to support students' individual development of self-regulated learning strategies to make them more effective learners. This activities will be reported in the near future after the collection of sufficient data from students and mentors.

- Development of an optimal Student Recruiting Model leading to the selection of participating State College students and equivalent controls. The objective of this project component is to implement a recruitment model for student participation at each State College that is feasible in terms of maximizing the number of recruits and that can be replicated by others interested in this model.

- Development of a computer-oriented student learning community. The objective of this project component is to provide participating students with future-oriented motivation to complete their State College AA degree and their BS degree in computer science at FAU. In the project, the learning community will provide students with three key elements: (a) extended collegial connections with other student participants as well as opportunities for them to join student engineering clubs. (b) ongoing contact with regional high-tech corporate representatives outlining professional and career-related opportunities and eventual internships, and (c) knowledge of state-of-the-art ongoing technological developments in computer science presented by FAU computer science faculty and students. Considered together, the student learning community provides students with perspectives of possible career opportunities based upon their completing their undergraduate degrees in computer science. 


\section{University-State College Collaboration}

\section{(a) Description of the Partnering Institutions}

Florida Atlantic University (FAU) is a large, diverse, degree granting institution (180 undergraduate and graduate degree programs) located in south Florida and is designated as a "High Research Activity" university by the Carnegie Foundation for the Advancement for Teaching. FAU serves over 30,000 undergraduate and graduate students and ranks as the most racially, ethnically diverse institution in Florida. The College of Engineering and Computer Science and the Department of Computer \& Electrical Engineering and Computer Science (CEECS) are located on the main campus. All the undergraduate degree programs in the College are accredited by the Accreditation Board of Engineering and Technology (ABET). The College offers a flexible schedule of courses delivered through a variety of formats (e.g., e-learning, distance learning, daily-recorded live lectures, downloadable video streaming, podcasts, and interactive video courses broadcast to remote locations and featuring two-way audio and video). It also offers internships with over 30 business/industry partners and an Innovation Leadership Honors Program with training in innovation, entrepreneurship, leadership, and sustainability. Broward College (BC) serves more than 67,000 students annually of which $35 \%$ are identified as Hispanic in academic year 2015 - 2016. The percentage of enrolled students eligible for Pell grants in 2014 - 2015 was even higher $-55 \%$. BC has made its mission to serve students with limited means who can choose from among 132 Bachelor's, Associate's and certificate programs and classes offered online and on-campus. BC boasts a student body representing more than 175 countries and $37 \%$ of BC's student body was born outside of the United States. BC is one of the nation's largest institutions of its type and ranks fifth nationally among four-year institutions in awarding Associate degrees, according to Community College Week, and third in the nation in awarding Associate's degrees to minority students, according to Diverse: Issues in Higher Education.

Palm Beach State College (PBSC) serves more than 48,000 students of which $27.5 \%$ are Hispanic and 53\% of full-time students eligible for need-based aid (as of 2014). PBSC offers 130 degree programs and 13 main areas of study of which two are focused on Computer Science \& Information Technology and Science \& Environment. PBSC is the $11^{\text {th }}$ largest producer of Associate of Arts degrees in the nation (Community College Week). Its two-year, AA university transfer degree is a requirement for the present project.

The three participating institutes have a large percentage of women (FAU - 51\% female, BC $56 \%$ female, PBSC $-56 \%$ female) and minority students and can provide a positive climate for their recruitment and retention.

\begin{tabular}{|cccc|}
\hline Institution & Student Population & Minority & Women \\
BC & 67,000 & $79 \%$ & $51 \%$ \\
PBSC & 48,966 & $56.6 \%$ & $56 \%$ \\
FAU & 30,808 & $51.1 \%$ & $56 \%$ \\
\hline
\end{tabular}

Table 1. Demographics and Student Population 


\begin{tabular}{|l|r|r|r|}
\hline Institutions & $\begin{array}{c}\text { Enrollment in AA } \\
(\mathbf{2 0 1 6 - 2 0 1 7 )}\end{array}$ & $\begin{array}{c}\text { Enrollment in AA } \\
\text { (URM) }\end{array}$ & $\begin{array}{c}\text { Enrollment in AA } \\
\text { (Female) }\end{array}$ \\
\hline BC & 38,474 & 17,698 & 22,626 \\
\hline PBSC & 18,890 & 11,828 & 10,459 \\
\hline
\end{tabular}

Table 2. Headcounts - Broward College and Palm Beach State College

\begin{tabular}{|l|l|l|l|}
\hline Major & $\begin{array}{l}\text { Enrollment } \\
\mathbf{( 2 0 1 5 - 2 0 1 6 )}\end{array}$ & $\begin{array}{l}\text { Enrollment } \\
\text { (URM) }\end{array}$ & $\begin{array}{l}\text { Enrollment } \\
\text { (Female) }\end{array}$ \\
\hline Computer Sci. & 512 & $46 \%$ & $13.9 \%$ \\
\hline Computer Eng. & 185 & $50.1 \%$ & $10.8 \%$ \\
\hline Electrical Eng. & 216 & $46 \%$ & $11.1 \%$ \\
\hline Civil Eng. & 275 & $45 \%$ & $22.3 \%$ \\
\hline Mechanical Eng. & 383 & $41.5 \%$ & $9.4 \%$ \\
\hline Ocean Eng. & 140 & $19.3 \%$ & 17.9 \\
\hline College Overall & 1711 & $44.6 \%$ & $13.7 \%$ \\
\hline
\end{tabular}

Table 3. Headcounts - FAU Engineering/CS Disciplines

\section{(b) Student Support}

Cultural competency is an important consideration in the design of this program and a critical ingredient for developing Florida's high-tech workforce. Students working in culturally diverse settings gain more global perspectives and demonstrate enhanced complex thought processes as a result. Increasing the diversity of the STEM workforce in computer occupations gives Florida's workforce a competitive edge in the global market. The program has designed to maximize the advantage of one of the largest and most diverse populations of learners in the state of Florida. The $\mathrm{BC}$ and PBSC student populations reflect the socioeconomic and ethnic diversity of the South Florida area, with a majority of the enrolled students hailing from minority backgrounds.

The articulation program has intended to build a sustainable and growing pipeline of students enrolling in Computer Engineering and Computer Science majors. The implementation of the program has centered on student success. As we prepared the program, we asked, "What do students need to successfully decide/get into college?" In addition to the reducing the worry about how they would pay for College, we recognized that students need support in terms of mentoring and advising that have been incorporated into the program. Training instructors, advisors, college counselors/other mentors have provided them the tools they need to keep students informed about college choices. Students have been assisted in finding the best choice of computer science or computer engineering program to match their interests and skills as well as to facilitate completion of applications and financial aid forms.

\section{(c) Targeted Programs and Progress}

The goal of the articulation program was to develop a sustainable education pipeline from South Florida high schools to three higher education institutions in South Florida - FAU, BC and PBSC. The proposed pipeline has intended to create an innovative and effective pathway that prepares students for successful careers in computer occupations. Participating students need to 
satisfy rigorous core requirements and customize their track and their electives. The first associate's degrees conferred by the articulation program have occurred in the spring of 2016. The articulation agreement promote the increased on production of bachelor's degrees in Computer Science and Computer Engineering. Engineers in this high- demand field are responsible for developing a wide array of technology including: sensors, microchips, robotics, circuit boards, personal computers, mobile phone applications, software and database systems. Currently, the BS degree in Computer Science requires a minimum of 120 credits. The BS in Computer Engineering requires a minimum of 128 credits. Students have been admitted to the program as freshmen at FAU or as transfer students from the State Colleges.

\begin{tabular}{|l|l|l|}
\hline Task & Timeline & Progress \\
\hline Program Planning & Spring 2014 & $\begin{array}{l}\text { Completed } \\
\text { Final Articulation Agreement Dec. 2014 }\end{array}$ \\
\hline $\begin{array}{l}\text { Curriculum Sub-Committee } \\
\text { Meeting }\end{array}$ & Spring 2014 & Began in Spring 2014 and Ongoing \\
\hline $\begin{array}{l}\text { Approval of Curriculum Mapping } \\
\text { (AA-BS) }\end{array}$ & Spring 2014 & Completed Dec. 2014 \\
\hline $\begin{array}{l}\text { Planning Meetings: Steering } \\
\text { Committee/Faculty and Advisors }\end{array}$ & Spring 2014 & Began in Spring 2014 and Ongoing \\
\hline $\begin{array}{l}\text { Program Dissemination and } \\
\text { Web Design }\end{array}$ & $\begin{array}{l}\text { Spring 2014/ } \\
\text { Summer 2014 }\end{array}$ & $\begin{array}{l}\text { Completed } \\
\text { capture-program.net }\end{array}$ \\
\hline $\begin{array}{l}\text { Design and Implementation of } \\
\text { Program Infrastructure at BC, PBSC } \\
\text { and FAU }\end{array}$ & Summer 2014 & Completed Fall 2014 \\
\hline $\begin{array}{l}\text { Phase I. Assessment: Prepare for } \\
\text { Data Collection and Analysis of the } \\
\text { Program }\end{array}$ & Fall 2014 & Completed Fall 2014 \\
\hline $\begin{array}{l}\text { Approval Process for AS to BS for } \\
\text { curriculum mapping and model at } \\
\text { the Dept. level }\end{array}$ & Fall 2014 & Completed for PBSC; 2014 \\
\hline $\begin{array}{l}\text { College and University Level } \\
\text { Approval for AS to BS Degree }\end{array}$ & Spring 2015 & Completed for PBSC; 2014 \\
\hline $\begin{array}{l}\text { Admission of the Second Cohort of } \\
\text { Students into CAPTURE Program }\end{array}$ & Summer 2015 & Completed \\
\hline $\begin{array}{l}\text { Completion Phase of program } \\
\text { infrastructure at 3 Institutions }\end{array}$ & Summer 2015 & Completed \\
\hline First cohort graduates (AA-BS) & Spring 2016 & Completed \\
\hline $\begin{array}{l}\text { Phase II Assessment: } \\
\text { Data Collection related to the } \\
\text { curriculum and student learning at } \\
\text { three Institutions }\end{array}$ & Summer 2019 & In Progress \\
\hline HIS Title III Project & Fall 2017-Fall 2022 & In Progress \\
\hline
\end{tabular}

Table 4. Timeline for Completion of Program Planning and Activities 


\section{Performance Metrics}

This section of the paper provides data on four areas of performance and outcome. First, data are presented for upper division enrollment in the CS/CE academic programs. Second, data are presented for the number of bachelor's degrees earned in the two mentioned academic programs. Third, completion rates for academic programs are provided. Fourth, post-baccalaureate (completer) outcomes are provided for students earning a bachelor's degree from CE \&CS programs.

\section{a) Upper Division Enrollments}

TABLE 5: Unduplicated Upper Division Headcount Enrollments in Targeted Programs

\begin{tabular}{|l|l|l|c|c|c|c|c|}
\hline \multirow{2}{*}{$\begin{array}{l}\text { Institution } \\
\text { Name }\end{array}$} & \multirow{2}{*}{$\begin{array}{l}\text { Data } \\
\text { Type }\end{array}$} & $\begin{array}{l}\text { Current } \\
\text { Year }\end{array}$ & Year 1 & Year 2 & Year 3 & Year 4 & Year 5 \\
\cline { 3 - 9 } & & $(2012-13)$ & $(2013-14)$ & $(2014-15)$ & $(2015-16)$ & $(2016-17)$ & $(2017-18)$ \\
\hline
\end{tabular}

Florida Atlantic University - Computer Science (11.0701), and Computer Engineering(14.0901)

\begin{tabular}{|l|l|l|r|r|r|r|r|}
\hline & Actual & $\mathbf{4 6 3}$ & $\mathbf{4 3 3}$ & $\mathbf{6 1 7}$ & $\mathbf{6 8 9}$ & $\mathbf{7 4 3}$ & \\
\hline & Projected & $\mathbf{4 6 3}$ & $\mathbf{4 7 6}$ & $\mathbf{4 8 9}$ & $\mathbf{5 0 2}$ & $\mathbf{5 1 5}$ & $\mathbf{5 2 8}$ \\
\hline & Expected & $\mathbf{4 6 3}$ & $\mathbf{5 2 2}$ & $\mathbf{5 7 0}$ & $\mathbf{6 7 7}$ & $\mathbf{7 4 0}$ & $\mathbf{8 1 0}$ \\
\hline
\end{tabular}

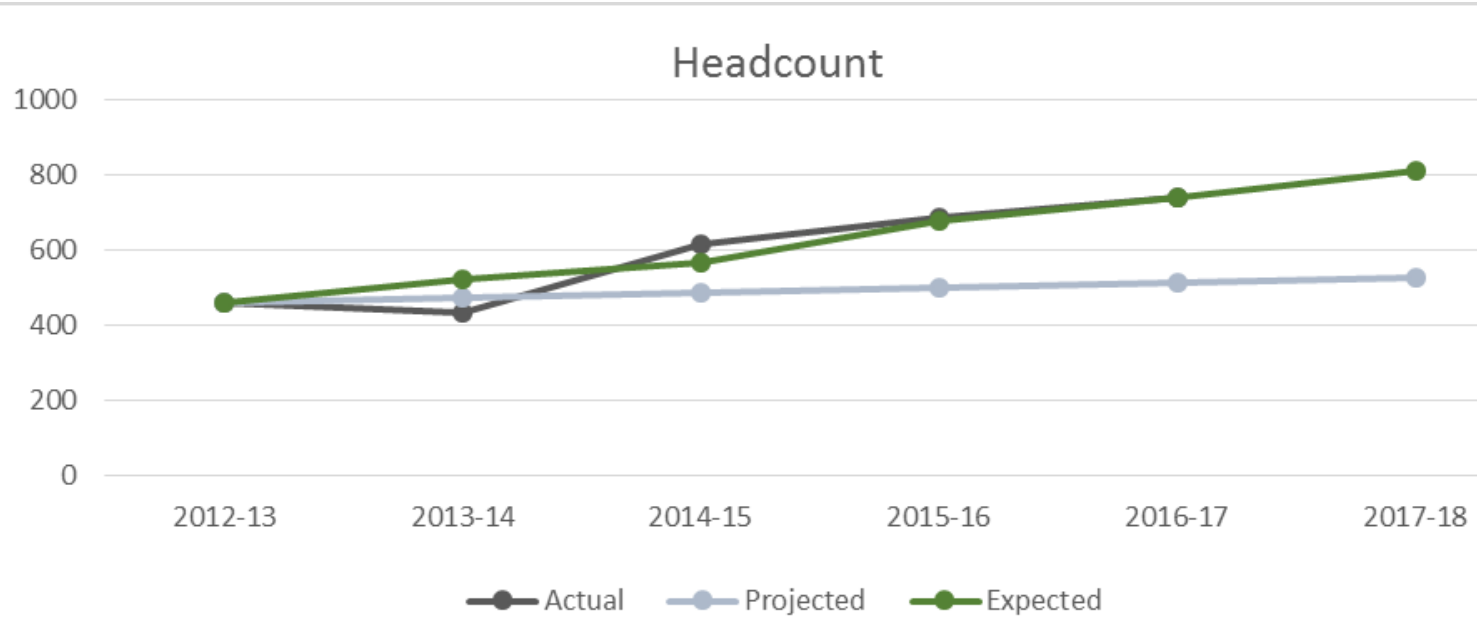

Pipeline

- The Program at BC has reported a total of 63 students majoring in computer science pursuing an A.A. degree with 52 students transferred to FAU this academic year. A total of eighteen (18) students are expected to transfer to FAU in fall 2017.

- The CAPTURE Program at PBSC has enrolled 148 students for the summer 2017 semester. Twenty (20) students are projected to transfer from PBSC to FAU by the end of summer 2017 semester. A total of 77 students transferred from PBSC to FAU during 2016-2017 academic.

Figure 2: Five years Upper Division pipeline (2012-2018)

As Table 5 shows, the number of upper division enrollments during the 2016-2017 academic year has increased $\mathbf{7 . 8 4} \%$ from the previous year, exceeding the expected performance measure in our application proposal. In addition, given the number of pre-professional students majoring in CS/CE as well as the anticipated number of transfer students from BC and PBSC, the student headcount is on track to exceed the performance measure again in the 2016-2017 academic year similar to previous years. 


\section{b) Student transfer with AA Degree from State Colleges to FAU}

This section provide the collected data pertaining to the transferred students with AA degrees from $\mathrm{BC}$ and $\mathrm{PBSC}$ to FAU. As the program has progressed during the last four years, there are steady increase in number of students with AA degrees transferred to CS/CE programs to FAU. Below table presents the figures as reported by the State Collages during the last four years:

\begin{tabular}{|l|l|l|l|l|l|}
\hline AA Transfer & $\mathbf{2 0 1 3 - 1 4}$ & $\mathbf{2 0 1 4 - 1 5}$ & $\mathbf{2 0 1 5 - 1 6}$ & $\mathbf{2 0 1 6 - 1 7}$ & $\mathbf{2 0 1 7 - 1 8}$ \\
\hline BC to FAU & 17 & 20 & 29 & 52 & \\
\hline PBSC to FAU & $\mathbf{2 3}$ & $\mathbf{3 7}$ & $\mathbf{4 3}$ & $\mathbf{7 7}$ & \\
\hline Total Transfer & $\mathbf{4 0}$ & $\mathbf{5 7}$ & $\mathbf{7 2}$ & $\mathbf{1 2 9}$ & \\
\hline
\end{tabular}

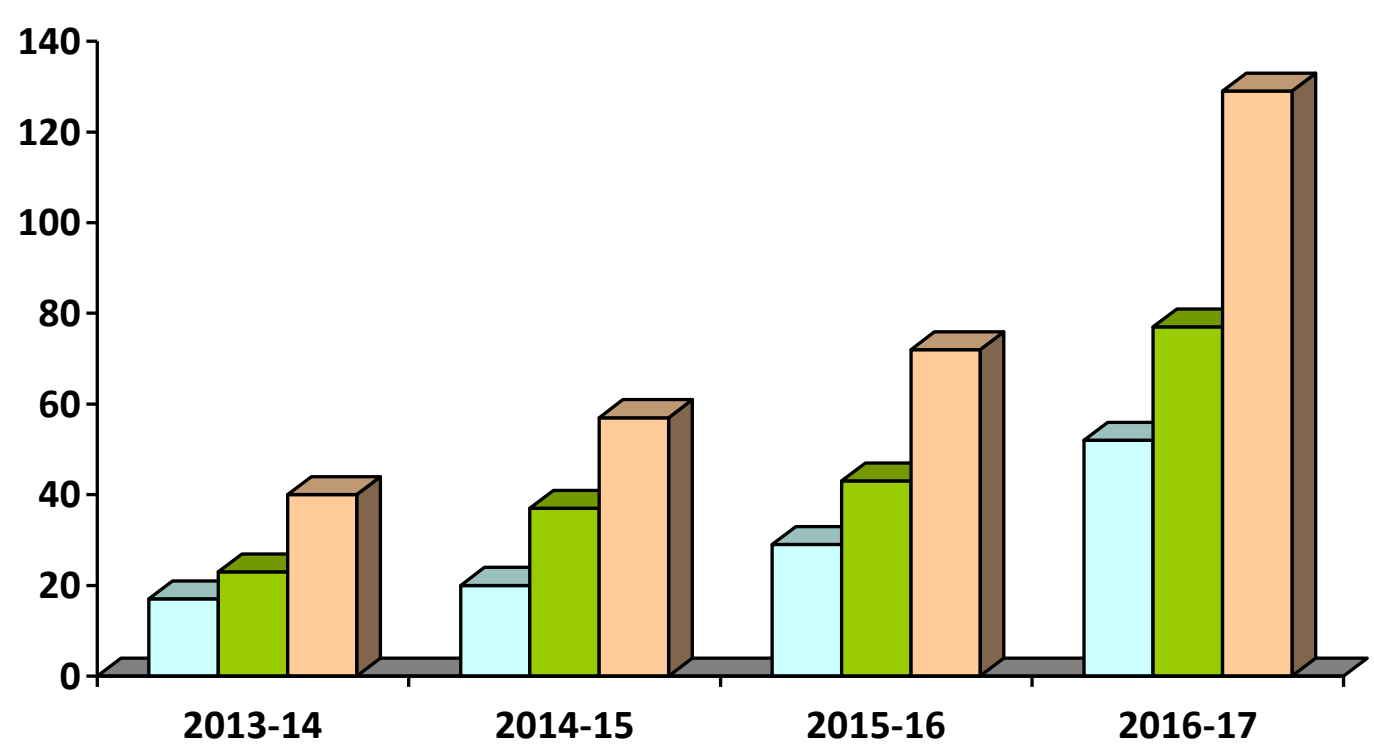

Figure 3- Transfer students with AA from State Colleges to FAU

\section{c) Bachelor's Degrees Earned}

\begin{tabular}{|c|c|c|c|c|c|c|c|}
\hline \multirow{3}{*}{$\begin{array}{l}\text { Institution } \\
\text { Name }\end{array}$} & \multirow{3}{*}{$\begin{array}{l}\text { Data } \\
\text { Type }\end{array}$} & \multicolumn{6}{|c|}{ Academic Year } \\
\hline & & $\begin{array}{l}\text { Current } \\
\text { Year }\end{array}$ & Year 1 & Year 2 & Year 3 & Year 4 & Year 5 \\
\hline & & $(2012-13)$ & $(2013-14)$ & $(2014-15)$ & $(2015-16)$ & $(2016-17)$ & $(2017-18)$ \\
\hline \multicolumn{8}{|c|}{ Florida Atlantic University - Computer Science and Computer Engineering } \\
\hline & Actual & 119 & 137 & 135 & 183 & 209 & \\
\hline & Projected & 119 & 126 & 133 & 140 & 147 & 154 \\
\hline & Expected & 119 & 130 & 146 & 182 & 204 & 225 \\
\hline
\end{tabular}




\section{BS Degrees Awarded}

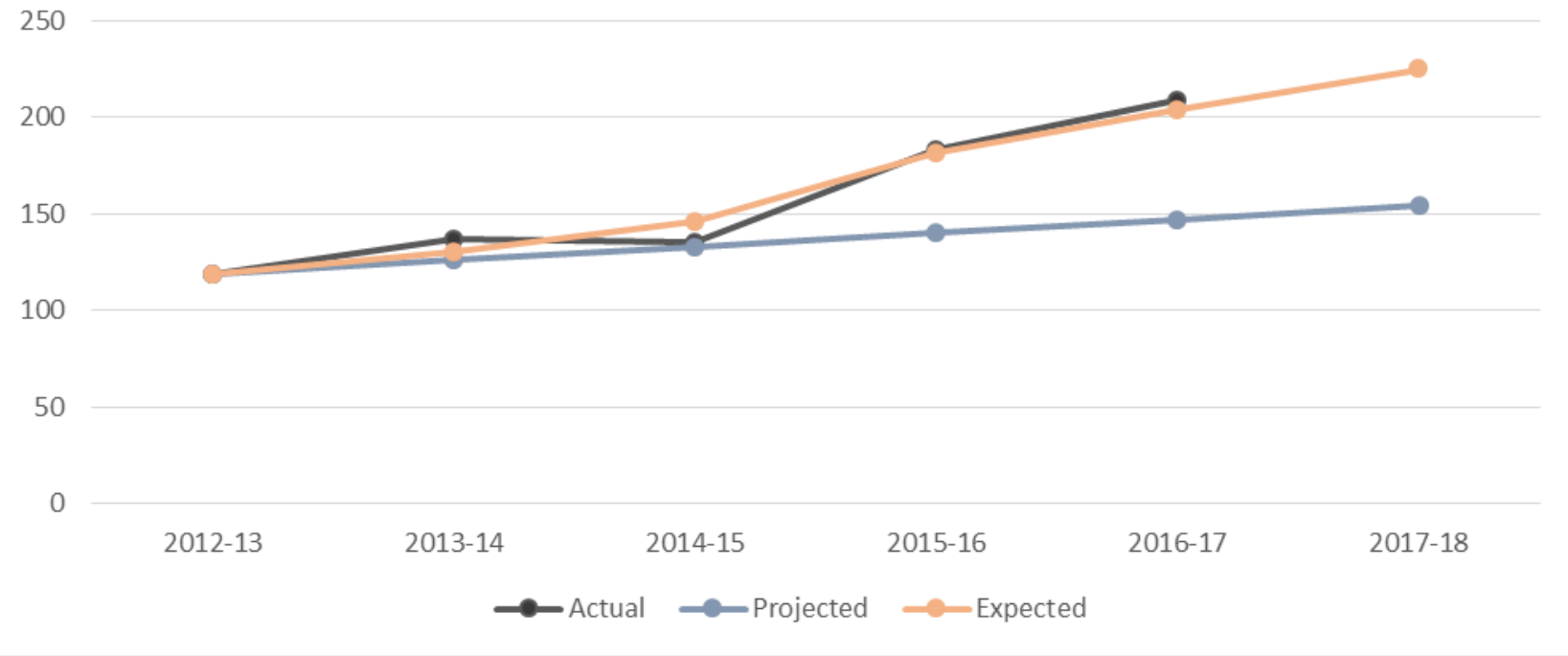

Figure 4: Five years Degree Earned in CS \&CE (2012-2018)

As Table 6 shows, the number of degreed awarded during the 2016-2017 academic year increased by $14.2 \%$ from the previous year, exceeding the expected performance measure in our application proposal. As the figures indicates the number of students earning BS degrees significantly increased this year. The figures above also included 11 graduates in general studies with computer Science concentration as their emphasis.

FAU expects to exceed the performance measures regarding BS degrees earned in the targeted programs for the next two years as substantial progress has been already made with the project objectives and overall infrastructure with BC and PBSC. With a newly funded HSI title II grant from Department of Education for the next five years, commitment to the sustainability of the program by all three institutions, completion of the on-line course offerings this academic year, and the significant increase in the $\mathrm{BC}$ and PBSC student enrollment in $\mathrm{CE} / \mathrm{CS}$ related AA programs, as well as the solidified partnership with BC and PBSC, the CAPTURE program is on course to significantly exceed the expected BS degrees earned in the targeted programs for the foreseeable future.

\section{d) Completion Rates}

TABLE 7: Unduplicated Upper Division Completion Rates in Targeted Programs

\begin{tabular}{|c|c|c|c|c|c|c|c|}
\hline \multirow{3}{*}{$\begin{array}{l}\text { Institution } \\
\text { Name }\end{array}$} & \multirow{3}{*}{$\begin{array}{l}\text { Data } \\
\text { Type }\end{array}$} & \multicolumn{6}{|c|}{ Academic Year } \\
\hline & & $\begin{array}{l}\text { Current } \\
\text { Year }\end{array}$ & Year 1 & Year 2 & Year 3 & Year 4 & Year 5 \\
\hline & & $(2012-13)$ & $(2013-14)$ & $(2014-15)$ & $(2015-16)$ & $(2016-17)$ & (2017-18) \\
\hline \multicolumn{8}{|c|}{ Florida Atlantic University - Computer Science (11.0701), and Computer Engineering (14.0901) } \\
\hline Totals & Actual & $59 \%$ & $62 \%$ & $70 \%$ & $76 \%$ & $76 \%$ & \\
\hline
\end{tabular}




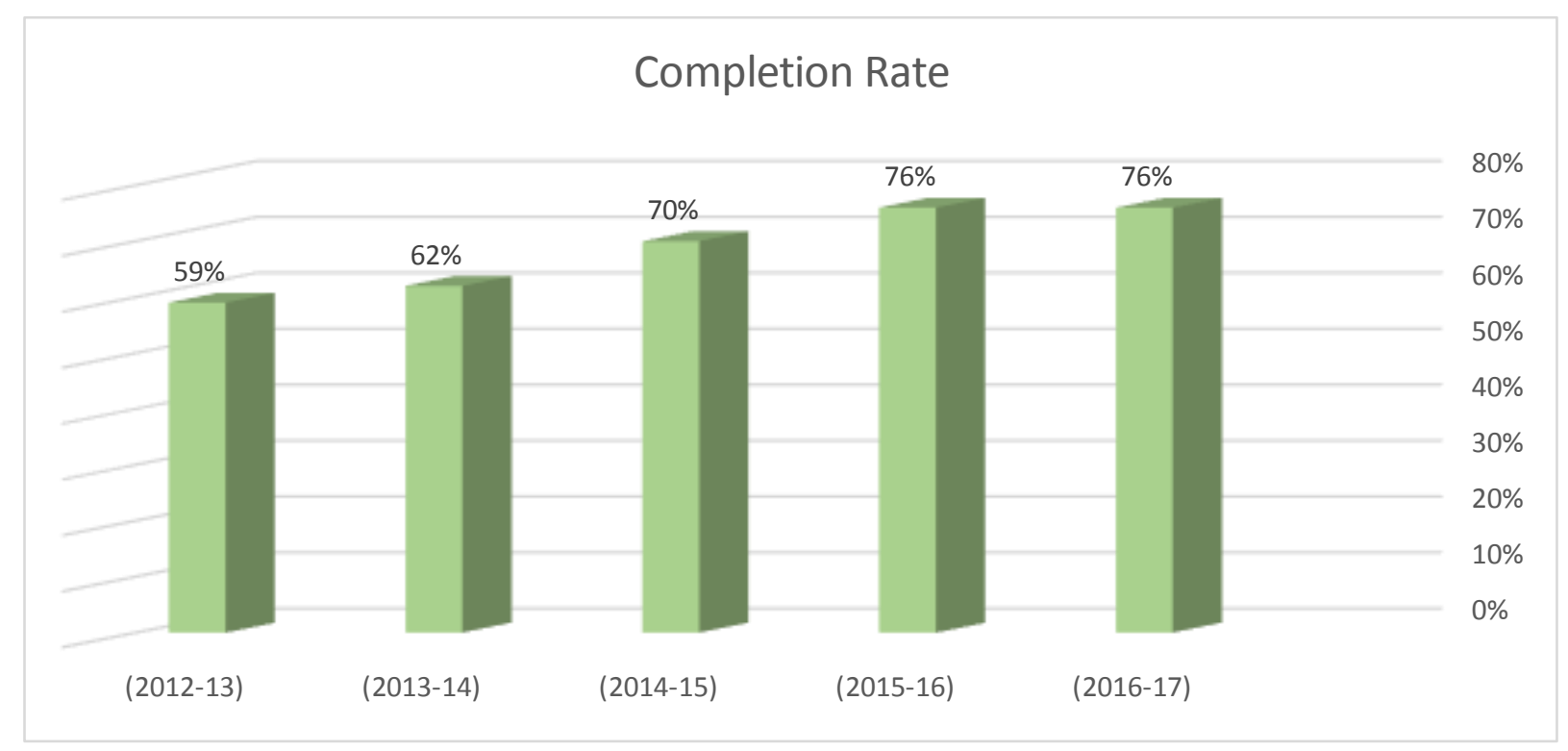

Figure 5: Five years Completion rate in CS \&CE (2012-2018)

As Table 7 indicates, the total completion rate in the targeted areas has been flat compared to last year at $76 \%$. However, the number of students that completed the upper division within a three years period increased by 25 headcount this year (379 students during 2016-2017 academic year vs 354 students for 2015-2016 AY). The completion rate increase is $17 \%$ in comparison of the first year of the CAPTURE program.

\section{(d) Completer Outcomes}

Evidence of post-baccalaureate (completer) outcomes is provided in this section. The data collected through surveys of graduates within the first year after earning their degree answers three fundamental questions. Do graduates get jobs? Where are they working? How much are they making?

The collected data are based on the post-graduation surveys that have been sent to all graduated students six months after the end of their graduation semester (fall, spring and summer). The analysis of collected data indicates that $51 \%$ (93 out of 124) who completed the survey are currently working in the State of Florida. According to the data, 24.2\% (30 out of 124) who completed the survey are attending graduate schools. Figures 5-9 presents more detailed information about the survey respondents. 


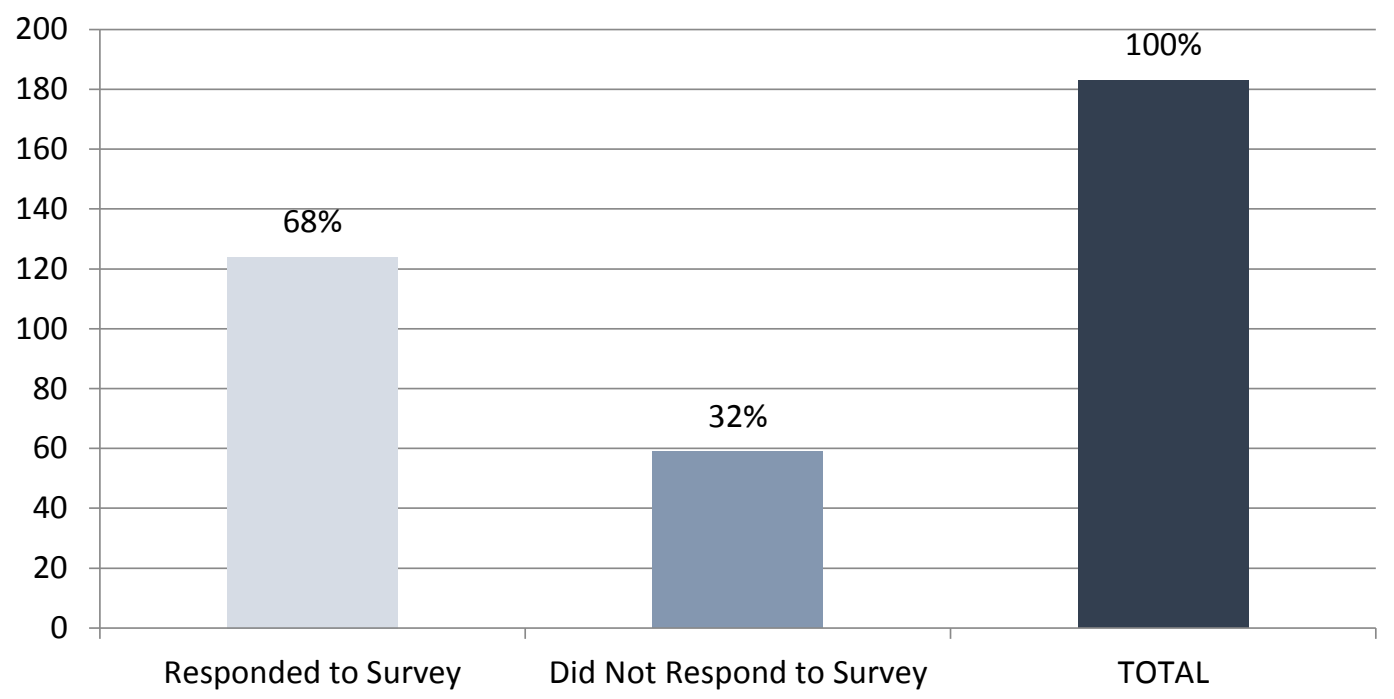

Figure 6. Respond/Did Not Respond Survey Result

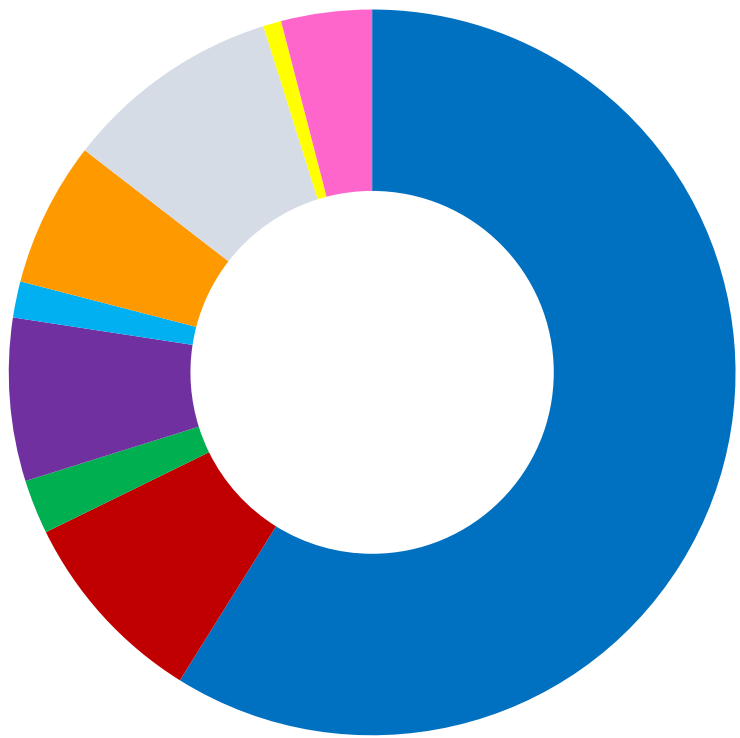

Working full-time, not enrolled

Working full-time, enrolled part-time

Working full-time, enrolled fulltime

Working part-time, not enrolled

Working part-time, enrolled part-time

Working part-time, enrolled full-time

Not working, not enrolled

Not working, enrolled parttime

Not working, enrolled full-time

Figure 7. Current Status of 2015-2016 Cohorts

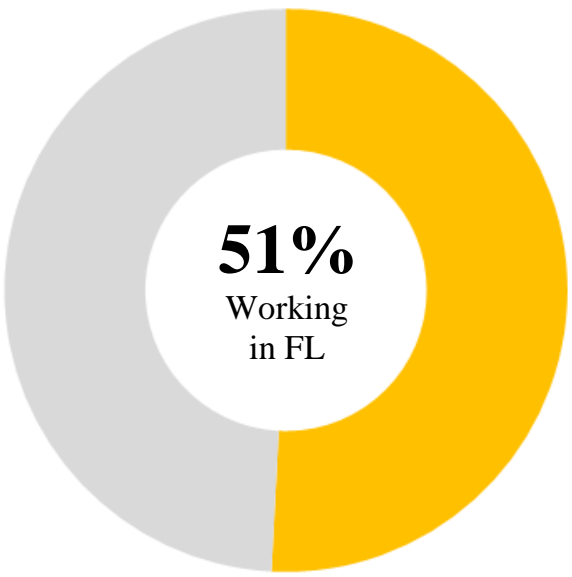

Figure 8. Location of 2015-2016 Cohort

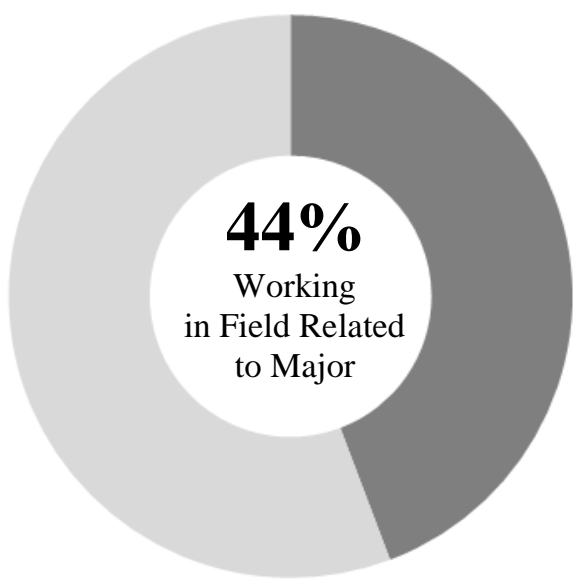

Figure 9. Field of Work for 2015-2016 Cohort 


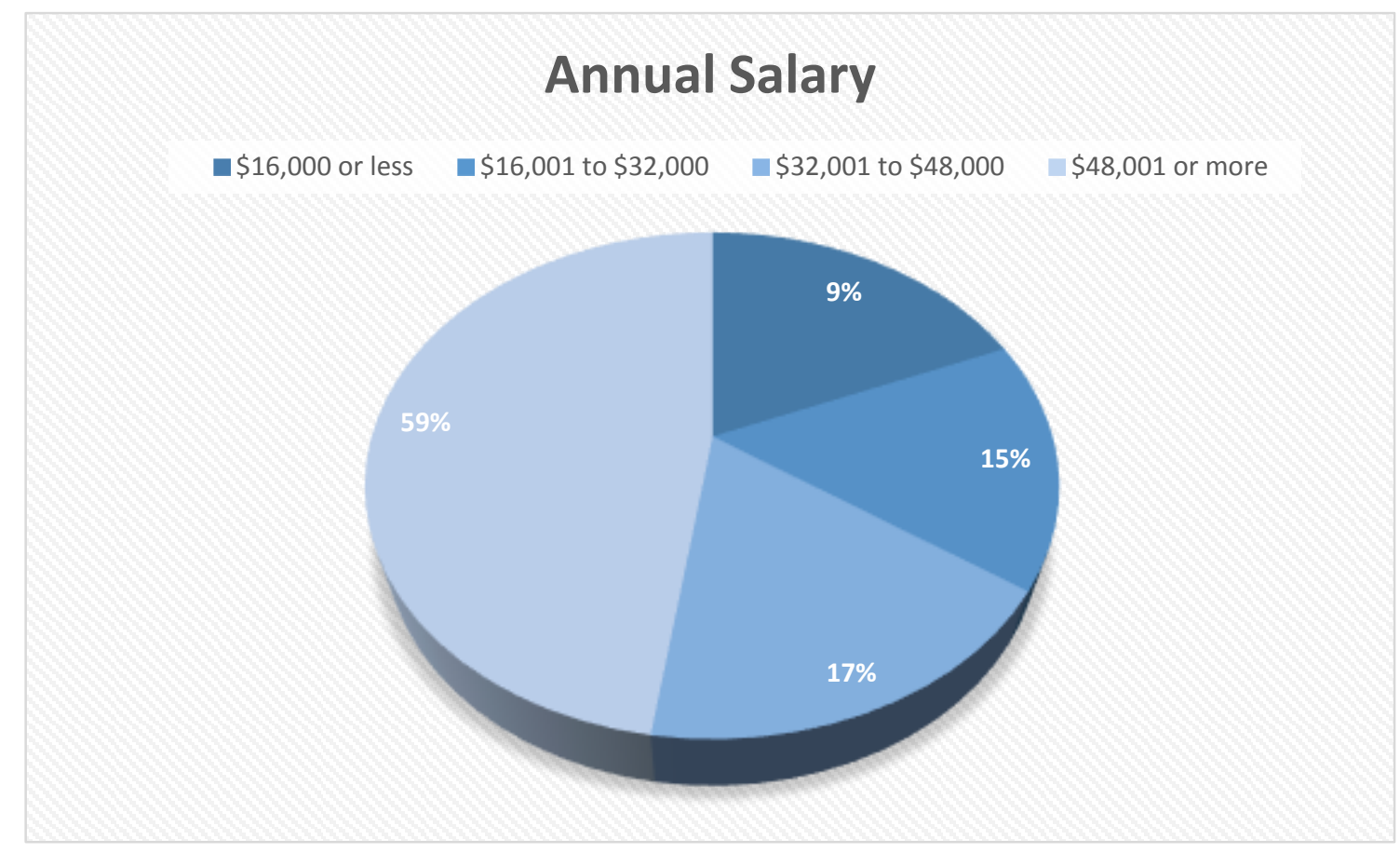

Figure 10. Annual Salary for 2015-2016 Cohort

\section{Program Advancement}

The program has provided Palm Beach State College, Florida Atlantic University, and Broward College a great opportunity to collaborate effectively for academic and career success of students. The following is a summary of the lessons learned:

- The initial implementation phase of the collaboration including curriculum mapping and articulation agreements between the three institutions has been a great success for the last four years. Other programs, especially in STEM-related-fields, could benefit from these approaches and tools to increase seamless admission and graduation rates for transfer students from State Colleges to State Universities in the Florida State system.

- The Articulation Agreements and Transfer Model have created a collaborative intervention and recruitment pathway between the three institutions. The Articulation Model is indeed a key component since the CAPTURE program has focused on facilitating the success of students who begin their CS degrees at 2-year state colleges (PBSC and BC) and then transfer as Juniors/Seniors to the 4-year university (FAU) where the CS/CE degree is offered. The CAPTURE Articulation Model is transportable to other settings in the State of Florida and beyond, and has been validated in its effectiveness in increasing the student pipeline and graduation rates in CS/CE. 
- The program has emphasized the student academic support facilitating course mastery through course-specific, mentor-led peer learning teams along with the concurrent development of student proficiency in self-regulated learning skills that allow them to become more effective independent learners in their future CS courses.

- The process has deepened our understanding of the needs of students who want to pursue Computer Science and Engineering programs, how to better help students achieve timely graduations, and better align student careers aspirations with industry workforce needs.

- Sharing resources among the campuses has proven to be of great value to both the students and the support staff at each college. Not only do the students benefit from the additional resources, but the staff also naturally share best practices and innovative teaching technologies.

- The program provided opportunities for academic success by: (1) providing scholarships to low-income students who need financial assistance, and (2) developing individualized advising and tutoring. The CAPTURE project also provided objective expectations by providing the flight plans.

- The Program created a strong communication pipeline between BC, PBSC and FAU, making the seamless transition of students possible, beneficial, and effective.

- Degree-specific flight plans and program-geared advising and tutoring have provided students with a kind of supplementary assistance that has proven to be highly contributory to their continued success. The scholarships they could receive through CAPTURE helped ease the financial burdens of their studies while also providing an incentive to achieve higher grades. Instead of coasting at the 2.5 GPA requirement for the program, many students worked even harder to meet the 3.0 requirement of the scholarship.

\section{$\underline{\text { Lessons Learned and Future Direction }}$}

With the above lessons learned, Florida Atlantic University has recently received a $\$ 4.4$ million grant from the U.S. Department of Education to increase the number of degrees awarded to Hispanic and low-income students in these fields, and to facilitate the rate of successful student post-degree computer science, computer engineering and electrical engineering/STEM employment or graduate school enrollment. This funded Hispanic Serving Institution project (Title III) helps eligible institutes of higher education to become self-sufficient and expand their capacity to serve low-income students by providing funds to improve and strengthen the academic quality and institutional management. It is a collaboration between FAU's College of Engineering and Computer Science, FAU's College of Education, Broward College (BC), and Palm Beach State College (PBSC). The new DOE project has focused specifically on the identified gateway courses that comprise part of the core curriculum content for the CS/CE degree programs and incorporate evidence-based ideas and recommendations from both discipline-specific education research as well as the broader ideas that drive instruction including the importance of aligning content, assessment and pedagogical practices. We expect to report on this transformative approach with new collected data in the near future. 


\section{References}

1. National Center for Education Statistics (NCEA) Report https://nces.ed.gov/programs/digest/d16/tables/dt16_105.20.asp?current=yes. [Access Date: March 18, 2018].

2. Department of Labor, Bureau of Labor Statistics; Projections overview and highlights, 20162026, https://www.bls.gov/opub/mlr/2017/article/projections-overview-and-highlights2016-26.htm; [Access Date: March 18, 2018].

3. Department of Labor, Bureau of Labor Statistics; Occupational Outlook Handbook; 2018 https://www.bls.gov/ooh/Computer-and-Information-Technology/Softwaredevelopers.htm\#tab-6; [Access Date: March 18, 2018].

4. US News and World Report, Best Technology Jobs, 2017 https://money.usnews.com/careers/best-jobs/software-developer[Access Date: March 18, 2018].

5. Carnevale, A.P., Smith, N. \& Strohl, J. Recovery: Job Growth and Education Requirement through 2020. Requirement, Washington, DC: Center on Education and the Workforce (https://cew-7632.kxcdn.com/wp-content/uploads/2014/11/Recovery2020.ES_Web_.pdf) [Access Date: March 18, 2018].

6. Dean L. Colson (Commission Chair), Board of Governors, State of Florida; Florida Access and Educational Attainment Committee Report, 2013.

7. National Research Council, Learning science in informal environments: People, places and pursuits. Committee on Learning Science in Informal Environments, P. Bell, B. Lewenstein, A.W. Shouse, and M. A. Feder (Eds.). Board on Science Education, Center for Education, Division of Behavioral and Social Sciences and Education. Washington, DC: The National Academies Press, 2009.

8. National Research Council; Expanding underrepresented minority participation: America's science and technology talent at the crossroads, Committee on the Underrepresented Groups and Expansion of the Science and Engineering Workforce Pipeline. F. A. Hrabowski, P. H. Henderson, \& E. Psalmonds (Eds.). Board on Higher Education and the Workforce, Division on Policy and Global Affairs. Washington, DC: The National Academies Press, 2011.

9. National Research Council; Discipline-based education research: Understanding and improving learning in undergraduate science and engineering. S.R. Singer, N.R. Nielsen, \& H.A. Schweingruber, (Eds.). Committee on the Status, Contributions, and Future Directions of Discipline-Based Education Research. Board on Science Education, Division of Behavioral and Social Sciences and Education. Washington, DC: The National Academies Press, 2012.

10. National Research Council; Future directions for NSF advanced computing infrastructure to support U.S. science in 2017-2020. Computer Science and Telecommunications Board; Division on Engineering and Physical Sciences. Washington, DC: The National Academies Press, 2016.

11. National Academies of Sciences, Engineering, and Medicine; Barriers and opportunities for 2-year and 4-year STEM degrees: Systemic change to support students' diverse pathways. Committee on Barriers and Opportunities in Completing 2-year and 4-year STEM Degrees, 
Board on Science Education, Board on Higher Education and the Workforce. Washington, DC: The National Academies Press, 2016.

12. National Academy of Engineering; Changing the conversation: Messages for improving public understanding of engineering. Committee on Public Understanding of Engineering Messages. Washington, DC: The National Academies Press, 2008.

13. National Academy of Engineering and American Society for Engineering Education, (2014). Surmounting the barriers: Ethnic diversity in engineering education: Summary of a workshop. Washington, DC: The National Academies Press, 2014.

14. National Academy of Engineering; Grand Challenges for Engineering: Imperatives, Prospects, and Priorities. Washington: National Academies Press, 2016

15. Woolsey, S. A. \& Shepler, D. K.; Understanding the early integration experiences of firstgeneration college students. College Student Journal. 45, 4, 700-714, 2011.

16. Antonio, A.L., Chang, M.J., Hakuta, K, Kenny, D.A., Levin, S. \& Milem, J.F. , Effects of racial diversity on complex thinking in college students. Psychological Science. 15, 8, 507-510, 2004.

17. Bressoud, D.; Attracting and retaining students to complete two-and four-year undergraduate degrees in STEM: The role of undergraduate mathematics education. Commissioned paper prepared for the Committee on Barriers and Opportunities in Completing 2-Year and 4-Year STEM Degrees, National Academy of Sciences, Washington, DC., 2014,

18. Bransford, J. D., Brown, A. L., \& Cocking, R. R. (Eds.). (2000). How people learn. Washington, DC: National Academy Press, 2000.

19. Carpenter, S. K., Cepeda, N. J., Rohrer, D., Sean, H. K., \& Pashler, H. (2012). Using spacing to enhance diverse forms of learning: Review of recent research and implications for instruction. Educational Psychology Review, 24, 369-378, 2012.

20. Pashler, H., Bain, P., Bottge, B., Graesser, A., Koedinger, K., McDaniel, M., \& Metcalfe, J. (2007). Organizing instruction and study to improve student learning (NCER 2007-2004).

Washington, DC: National Center for Education Research, Institute of Education Sciences, U.S. Department of Education, 2007. Retrieved from http://ncer.ed.gov.

21. President's Council of Advisors on Science and Technology; Report to the President: Engage to excel: Producing one million additional college graduates with degrees in science, technology, engineering and mathematics, 2012. Available: http://www.whitehouse.gov/sites/default/files/microsites/ostp/pcast-engage-to-excelfinal_feb.pdf.

22. What Works Clearinghouse (WWC) Preview of regression discontinuity design standards, 2015. Retrieved from http://ies.ed.gov/ncee/wwc/documentsum.aspx?sid=258

23. Wilson, Z. S., Holmes, L., deGravelles, K., Sylvain, M. R., Batiste, L., Johnson, M., McGuire, S. Y., Pang, S. S., \& Warner, I. M. (2012). Hierarchical mentoring: A transformative strategy for improving diversity and retention in undergraduate STEM disciplines. Journal of Science Education and Technology, 21(1), 148-156, 2012.

24. Zilouchian, A.; CAPTURE Project Reports: Computer accelerated pipeline to unlock regional excellence. Targeted Educational Attainment (TEAm) Grant Program. Tallahassee, FL: Florida Board of Governors, State University System of Florida; 2014-2017. 